International Journal of Advanced Research in Engineering and Technology (IJARET)

Volume 12, Issue 4, April 2021, pp. 518-533, Article ID: IJARET_12_04_050

Available online at https://iaeme.com/Home/issue/IJARET?Volume=12\&Issue=4

ISSN Print: 0976-6480 and ISSN Online: 0976-6499

DOI: https://doi.org/10.34218/IJARET.12.4.2021.050

(C) IAEME Publication

Scopus Indexed

\title{
THE STATE OF WOMEN DIGITAL ENTREPRENEURS IN INDIA DURING COVID-19 PANDEMIC
}

\author{
G. Lakshmi Priya1, Dr. S. Smilee Bose ${ }^{2}$ \\ ${ }^{1}$ Full-Time Research Scholar, Department of Commerce, \\ St. Peter's Institute of Higher Education and Research, \\ St. Peters University, Tamil Nadu, India \\ ${ }^{2}$ Research Supervisor, Associate Professor, Department of Commerce, \\ St. Peter's Institute of Higher Education and Research, \\ St. Peters University, Tamil Nadu, India
}

\begin{abstract}
During the Last two decades, the growth of Women Digital Entrepreneurs in India has been increasing tremendously with the high level contribution towards economic progress. In India, a Nationwide Coronavirus lockdown made many business to terminate. The impact of COVID-19 has affected not only many human lives but also economic activity of business. This pandemic and subsequent lockdowns created more restrictions on Travelling and Business. In this situation, Digital Business is most considered and best way of selling and purchasing different types of goods and services in order to avoid direct contact and physical distance of human. The Coronavirus has transformed the global digital business trends. The contribution of Women Entrepreneurs in India is at significant level in economic development but women-led business have been negatively affected due to Covid-19 as Women have to deal with difficulties not only caused by Coronavirus but also management of business as well their family responsibilities. This study determines the status of Women digital entrepreneurs in India during Covid-19 Pandemic. For this, study involved survey of 100 Women entrepreneurs doing online business in India to understand the Impact of Covid-19 on Women Entrepreneurs and Strategies used by Women Digital Entrepreneurs in continuing their business during COVID-19.
\end{abstract}

Key words: COVID-19, Pandemic, Lockdowns, Digital Business, Strategies, Women Digital Entrepreneurs.

Cite this Article: G. Lakshmi Priya and S. Smilee Bose, The State of Women Digital Entrepreneurs in India During Covid-19 Pandemic, International Journal of Advanced Research in Engineering and Technology, 12(4), 2021, pp. 518-533.

https://iaeme.com/Home/issue/IJARET?Volume=12\&Issue $=4$ 


\section{INTRODUCTION}

Women digital Entrepreneurs is a single Women or group of Women who starts, organizes and operates a digital business enterprise with confident, creative and design economic independence individually and creates employment opportunities for others. Women Digital Entrepreneurs also refers to online women entrepreneurs who sells their products and services on digital platform with the capacity of bearing most of risks and expected most of rewards.

As the COVID-19 Pandemic evolves around the world, Many Countries have formulated various strategies to curb the COVID-19 spread. For this, India have been in a several stages of Lockdown by restricting movement and business as usual.

Quarantine 1: $25^{\text {th }}$ March 2020- $14^{\text {th }}$ April 2020 (21 Days)

Quarantine 2: $15^{\text {th }}$ April 2020- $3^{\text {rd }}$ May 2020 (19 Days)

Quarantine 3: $4^{\text {th }}$ May 2020- $17^{\text {th }}$ May 2020 (14 Days)

Quarantine 4: $18^{\text {th }}$ May $2020-31^{\text {st }}$ May 2020 (14 Days)

Quarantine 5 (only for CoronaVirus Contaiment Zone) $1^{\text {st }}$ June $2020-30^{\text {th }}$ June 2020 (30 Days)

COVID-19 Pandemic has been a difficult time for the entire world economic system as it results in pay cuts and lay off. Coronavirus radically changes the behaviour of human, nature of business and even the way of their living. This situation has caused a fear among the people to avoid interacting with others. In order to cope up with this crisis, people are forced to adapt to digital technology. COVID-19 has forced business organisations to undergo digital transformation to adjust with current situation.

Women Entrepreneurs are considered as Back Bone of Indian Economy as they contribute in generation of various sources of income, create employment opportunities, enhance innovation and competition, develops skills and improve standard of living of society. The COVID-19 Pandemic has negatively impacted Women Entrepreneurs. Women Entrepreneurs are severely affected by the economic shutdown. During this Pandemic role of digital technology started major role among Women Entrepreneurs. Women Entrepreneurs who already accessed to digitalization were able to adapt to this social distancing measures.

This study determines the impact of COVID-19 on Women Digital Entrepreneurs as well as Strategies adopted by them in continuing their business during COVID-19 pandemic.

\section{OBJECTIVES OF THE STUDY}

1.To study the impact of COVID-19 on Women Digital Entrepreneurs.

2. To discuss the strategies used by Women Digital Entrepreneurs in online business during COVID19 pandemic.

\section{REVIEW OF LITERATURE}

Ms.K.S.Susmitha ( September 2020)- "Impact of COVID-19 on E-Commerce". This article presented the status of E-Commerce during COVID-19. This study highlighted the increased use of E-Commerce during COVID-19 which benefitted people buying online. Researcher indicated the factors affected demand and buying behaviour of consumer in COVID-19.

Risqo M. Wahid, Diah Isnaini Asiati (February 2021)- "Women MSMEs and COVID-19 Social Media Marketing as a survival strategy". This study explored Social Media Marketing (SSM) strategy utilized by Women owned MSMEs in Indonesia during COVID-19 Pandemic. The finding of this study revealed that Women MSMEs implemented SSM strategies like posting, sharing, attractive contents, Word-of-Mouth, Follow-for-Follow, paid influence and native advertisement helped Women Entrepreneurs to survive during COVID-19 pandemic. 
Taiba Sardar, Zeng Jianqiv, Muhammad Bilal and Nausheen Syed (September 2020)- “ Impact of ICT on Entrepreneurial self-efficacy in emerging economy: Sustaining lockdown during COVID-19 Pandemic". This article investigated the impact of ICT on Entrepreneurial Self-Efficacy (ESE), Social Networking and facilitation to micro-entrepreneurs during COVID19 pandemic in Pakistan. This study resulted that survival of Micro-Entrepreneurs during the pandemic can be done through Information Communication Technology, as it has been considered as strong variable which helps Entrepreneurs in increasing their entrepreneurial activity in pandemic situation.

Inshan Meahjohn, Prakash Persad (2020)- "The Impact of COVID-19 on Entrepreneurship Globally". This article discussed about challenges experienced by entrepreneurs at the time of COVID-19 and suggested measures to be taken in order to protect their ventures. This paper concludes that COVID-19 has caused significant disruption to economies and entrepreneurship globally and recommended to take in-depth longitudinal studies on impact of COVID-19 on entrepreneurs as it remains unclear.

\section{RESEARCH METHODOLOGY}

This study is based on both Primary data and Secondary data. Primary data are collected using Questionnaire. Secondary data are collected through Journals, Books, Websites, and Published articles and Magazines related to this topic.

Sample Design: This study has adopted Qualitative approach to examine the status of Women Digital Entrepreneurs during COVID-19 Pandemic. For this, sample of 100 women entrepreneurs doing online business has been taken in and around various Districts of Tamil Nadu. Sampling is done on the basis of simple and stratified random sampling.

This study was conducted between $16^{\text {th }}$ March 2021- $31^{\text {st }}$ March 2021. The survey was conducted via Personal Google form link.

Data Analysing Tools: Data are analyzed by using Percentage method and SPSS techniques like One Sample t test, Independent Sample t test, Analysis of variance (ANOVA) techniques and Multivariate Analysis of Variance (MANOVA)

\subsection{Limitation of the Study}

- As the survey was conducted through Google form link there has been lack of Quality data collection as the respondent provides information spontaneous but may not be consistent.

- Though opinion drawn is based on the feedback of the respondents, it may not represent the opinion of the Universe.

- This research study suffers from the change in opinion of the respondents with respect to time.

\section{SUCESSFUL WOMEN DIGITAL ENTREPRENEURS IN TAMIL NADU}

In the last two decades, there has been increased use of internet and social media among Women Entrepreneurs. Which paves a way for many Women Entrepreneur's to be successful in converting their big ideas into powerful brands unlike, their traditional way of their business. Now a days Women Entrepreneurs are becoming impressive and inspirational to others in digital landscape. The emergence of Digital media has given Women Entrepreneurs the power of liberalisation right from education to economic liberty Some of the Women Digital Entrepreneurs in Tamil Nadu : 
The State of Women Digital Entrepreneurs in India During Covid-19 Pandemic

Table 1

\begin{tabular}{|c|c|c|c|}
\hline Organisation & Founder & Year Founded & \begin{tabular}{|c|} 
Industry \\
\end{tabular} \\
\hline Sulekha & Satya Prabhakar & 2007 & $\begin{array}{l}\text { Sulekha is a digital platform } \\
\text { for local service business for } \\
\text { consumers and business to } \\
\text { connect with each other }\end{array}$ \\
\hline BankBazzar & Rati Shetty & 2008 & $\begin{array}{l}\text { BankBazzar is a online } \\
\text { Platform which helps } \\
\text { consumers in comparing and } \\
\text { choosing insurance and } \\
\text { financial products }\end{array}$ \\
\hline Chrysalis & Chitra Ravi & 2001 & $\begin{array}{l}\text { Chrysalis is online education } \\
\text { platform of integrated } \\
\text { academic program for maths, } \\
\text { English, science, and social } \\
\text { studies in schools }\end{array}$ \\
\hline Wandertrails & Sruti Ramesh Chander & 2016 & $\begin{array}{l}\text { Wandertrails is a travel tech } \\
\text { online platform company } \\
\text { provides service of travel } \\
\text { bookings and } \\
\text { accommodation facilities. }\end{array}$ \\
\hline Adjutas & $\begin{array}{l}\text { Swathi Sethuraman } \\
\text { Rajasekaran Anita }\end{array}$ & 2015 & $\begin{array}{l}\text { Adjutas ia a cloud based } \\
\text { support helpdesk for } \\
\text { customer support and } \\
\text { internal IT teams. }\end{array}$ \\
\hline VIBIS Natural Bee Farm & Josephine Selvaraj & 2005 & $\begin{array}{l}\text { VIBIS is a Agricultural } \\
\text { cooperative which offers } \\
\text { variety of Honey product. }\end{array}$ \\
\hline Ravindra Services Pvt. Ltd & G.Sree Vidhya & 1997 & $\begin{array}{l}\text { Ravindra Services Pvt. Ltd } \\
\text { offers a variety of services } \\
\text { nationwide to individuals and } \\
\text { companies like security } \\
\text { services, Guarding services } \\
\text { etc.. }\end{array}$ \\
\hline $\begin{array}{l}\text { STC Technologies Private } \\
\text { Limited }\end{array}$ & Madhu Saran & 2003 & $\begin{array}{l}\text { STC Technologies is the } \\
\text { software testing education } \\
\text { and certification company } \\
\text { which provides services in } \\
\text { testing education \& } \\
\text { certification, testing contract } \\
\text { staffing and third party } \\
\text { Independent. }\end{array}$ \\
\hline myHarvest Farms & Archana Stalin & 2016 & $\begin{array}{l}\text { myHarvest - a social } \\
\text { enterprise, provides oil, } \\
\text { seeds, fertilizers and other } \\
\text { requisites for roof-top } \\
\text { gardening. }\end{array}$ \\
\hline WSquare & Vandhana and Jinal & 2017 & $\begin{array}{l}\text { WSquare is a women-only } \\
\text { co-working space in order to } \\
\text { encourage Women can } \\
\text { precent their products like } \\
\text { jewellery, clothes, food etc. }\end{array}$ \\
\hline $\begin{array}{l}\text { Women Entrepreneurs } \\
\text { India }\end{array}$ & Mahalakshmi Saravanan & 2018 & $\begin{array}{l}\text { Women Entrepreneurs India } \\
\text { offers support to women who } \\
\text { looks forward to start a } \\
\text { business by providing ideas } \\
\text { that match with their } \\
\text { abilities, interests and skills. }\end{array}$ \\
\hline
\end{tabular}




\section{ANALYSIS AND FINDINGS}

\subsection{Demographic Profile of Women Entrepreneurs}

Demographic factors of Women Entrepreneur's Age, Marital Status, Education Qualification, Experience, Ownership, Business Size and Type of business are analysed using One sample tTest.

\section{Hypothesis}

$\mathrm{H}_{01}: \mu=$ Average age of the respondents belongs to the age group of 20 years -30 years.

$\mathrm{H}_{02}: \mu=$ Average Marital Status of the respondents are Spinster

$\mathrm{H}_{03}: \mu=$ Average Education Qualification of the respondents have Under Graduate Degree

$\mathrm{H}_{04}: \mu=$ Average years of Experience of the respondents have in E-Business is 1year -3 Years.

$\mathrm{H}_{05}: \mu=$ Average number of respondents are Retailers.

$\mathrm{H}_{06}: \mu=$ Average size of the online business is small scale Business

$\mathrm{H}_{07}: \mu=$ Average kind of Business run by the Women Entrepreneurs is Beauty products and cosmetics.

Table 2 Demographic profile of the Respondents

\begin{tabular}{|c|c|c|c|c|c|c|c|c|}
\hline $\begin{array}{c}\text { Demographic } \\
\text { variables }\end{array}$ & $\begin{array}{c}\text { Class } \\
\text { Interval }\end{array}$ & $\begin{array}{l}\text { No. of the } \\
\text { Respondents }\end{array}$ & $\begin{array}{c}\text { Mean } \\
(\overline{\mathbf{x}})\end{array}$ & $\begin{array}{l}\text { Standard } \\
\text { Deviation }\end{array}$ & $\begin{array}{l}\text { Degree of } \\
\text { Freedom }\end{array}$ & $\begin{array}{c}\text { Test } \\
\text { Statistic } \\
\mathbf{T} \\
\end{array}$ & $\begin{array}{c}\text { Sig.. } \\
\text { (2Tailed) }\end{array}$ & $\begin{array}{c}\text { Mean } \\
\text { Difference }\end{array}$ \\
\hline Age Group & \begin{tabular}{|l|} 
Below 20 \\
Years \\
20 Years- 30 \\
Years \\
30 Years- 40 \\
Years \\
Above 40 \\
Years \\
\end{tabular} & $\begin{array}{l}19 \\
12\end{array}$ & 2.16 & 0.961 & 99 & 1.665 & 0.099 & 0.160 \\
\hline Marital Status & \begin{tabular}{|l} 
Married \\
Spinster \\
Widow \\
Divorcee \\
\end{tabular} & \begin{tabular}{c|}
61 \\
30 \\
9 \\
0
\end{tabular} & 1.48 & 0.65874 & 99 & -7.894 & .000 & -0.52000 \\
\hline $\begin{array}{l}\text { Education } \\
\text { Qualification }\end{array}$ & \begin{tabular}{|l|} 
SSLC/HSC \\
Under \\
Graduate \\
Post Graduate \\
Professional \\
\end{tabular} & $\begin{array}{c}6 \\
71\end{array}$ & 2.25 & 0.68718 & 99 & 3.368 & .000 & 0.25000 \\
\hline $\begin{array}{l}\text { Experience in E- } \\
\text { Business }\end{array}$ & \begin{tabular}{|l|}
$0-1$ year \\
1 year- 3 \\
years \\
3 years- \\
5 years \\
Above 5 \\
years \\
\end{tabular} & $\begin{array}{l}49 \\
22\end{array}$ & 1.83 & 0.92174 & 99 & -1.844 & 0.068 & -0.17000 \\
\hline \begin{tabular}{|l|} 
Ownership \\
Structure
\end{tabular} & \begin{tabular}{|l|} 
Sole \\
Proprietor \\
Retailers \\
Partnership \\
Co-Operative \\
\end{tabular} & $\begin{array}{l}33 \\
16 \\
10 \\
\end{array}$ & 1.95 & 0.98857 & 99 & -0.506 & 0.614 & -0.05000 \\
\hline Size of Business & \begin{tabular}{|l|} 
Micro level \\
Business \\
Small Scale \\
Enterprises \\
Medium scale \\
Enterprises \\
\end{tabular} & 40 & 1.90 & 0.87039 & 99 & -1.149 & 0.253 & -0.10000 \\
\hline
\end{tabular}


The State of Women Digital Entrepreneurs in India During Covid-19 Pandemic

\begin{tabular}{|c|c|c|c|c|c|c|c|c|}
\hline & $\begin{array}{l}\text { Large Scale } \\
\text { Enterprises }\end{array}$ & 3 & & & & & & \\
\hline \multirow{14}{*}{ Kinds of Business } & \begin{tabular}{|l|} 
Online \\
Marketing
\end{tabular} & 17 & \multirow{14}{*}{4.7} & \multirow{14}{*}{3.51476} & \multirow{14}{*}{99} & \multirow{14}{*}{-6.544} & \multirow{14}{*}{0.000} & \multirow{14}{*}{-2.30000} \\
\hline & $\begin{array}{l}\text { Clothing and } \\
\text { Accessories }\end{array}$ & 13 & & & & & & \\
\hline & \begin{tabular}{|l|} 
Online \\
teaching
\end{tabular} & 14 & & & & & & \\
\hline & $\begin{array}{l}\begin{array}{l}\text { Food and } \\
\text { Catering } \\
\text { services }\end{array} \\
\end{array}$ & 15 & & & & & & \\
\hline & $\begin{array}{l}\text { Beauty } \\
\text { cosmetics and } \\
\text { services }\end{array}$ & 18 & & & & & & \\
\hline & \begin{tabular}{|l|} 
online \\
Consultancy \\
services
\end{tabular} & 3 & & & & & & \\
\hline & $\begin{array}{l}\text { Travelling } \\
\text { and Tourism } \\
\text { Services }\end{array}$ & 2 & & & & & & \\
\hline & \begin{tabular}{|l} 
online \\
Professional \\
Services
\end{tabular} & 1 & & & & & & \\
\hline & $\begin{array}{l}\text { Online Health } \\
\text { Care Services }\end{array}$ & 2 & & & & & & \\
\hline & \begin{tabular}{|l|l|} 
Event \\
Organizing \\
\end{tabular} & 3 & & & & & & \\
\hline & \begin{tabular}{|l} 
Web \\
Designing
\end{tabular} & 4 & & & & & & \\
\hline & Retail selling & 3 & & & & & & \\
\hline & $\begin{array}{l}\text { online Gifts } \\
\text { sellers }\end{array}$ & 3 & & & & & & \\
\hline & $\begin{array}{l}\text { online } \\
\text { bidding } \\
\text { services }\end{array}$ & 2 & & & & & & \\
\hline
\end{tabular}

(source: Primary)

Age of the surveyed respondents varied from below 20 years to above 40 years. Age of the respondents are categorized as below 20 years, 20- 30 years, 30-40 years and above 40 years. The frequency distribution of surveyed Women Entrepreneurs in terms of age has been shown in table 1.1. Since the p value (0.099) is More than (>) 0.05. Null Hypothesis $\left(\mathrm{H}_{0}\right)$ is Accepted at $5 \%$ level. Hence, Average age of the respondents belong to the age group of 20 years- 30 Years.

Marital status plays an important role in the field of male domination. The factors like worklife balance and family support depend of marital status of women. The marital status of the respondents are categorised into Married, Spinster, Widow and Divorcee. Since the $\mathrm{p}$ value $(0.000)$ is less than $(<)$ 0.05. Null Hypothesis $\left(\mathrm{H}_{0}\right)$ is Rejected at $5 \%$ level. Hence, Average Marital Status of the Respondents are Married.

Education Qualification is considered as important factor because education helps in acquiring knowledge and skills. It is considered as asset of an individual in building their career. Education Qualification of the respondents are categorised as SSLC/HSC, Under Graduate, Post Graduate and Professional. Since the p value (0.000) is less than $(<)$ 0.05. Null Hypothesis $\left(\mathrm{H}_{0}\right)$ is Rejected at 5\% level. Hence, Average Education Qualification of the Respondents does not have Under Graduate Degree.

Experience determines one's own ability in success. It is considered as important factor because it helps to make decision and create confidence in performing business activities. The frequency distribution of Women Entrepreneurs in terms of experience are classified into below 
one year, 1-3 years, 3-5 years and above 5 years. Since the p value $(0.068)$ is more than $(>)$ 0.05. Null Hypothesis $\left(\mathrm{H}_{0}\right)$ is Accepted at $5 \%$ level. Hence, Average years of Experience of the respondents have in E-Business is 1year - 3 Years.

Ownership structure of business include control of business, managerial ability, cost of formation, liability exposure and tax consideration. Ownership structure of the respondent's business are classified as sole proprietor, partnership, co-operative business and retail business. Since the p value (0.614) is more than (>) 0.05. Null Hypothesis $\left(\mathrm{H}_{0}\right)$ is Accepted at 5\% level..Hence, Average number of respondents are Retailers.

Size of business refers to scale of business and volume of business operation. It is depend on the number of employees in business. Size of business of the respondent's business are categorized as micro level business, small scale business, medium level business and large scale business. Since the p value $(0.253)$ is more than ( $>)$ 0.05. Null Hypothesis $\left(\mathrm{H}_{0}\right)$ is Accepted at $5 \%$ level. Hence, Average size of the online business is small scale Business.

Various forms of business is a key factor for determining the economic performance of Women Entrepreneurs. Women Entrepreneurs chooses the type of business according to their skills, knowledge, education, finances and convenience. Since the p value $(0.000)$ is less than $(<)$ 0.05. Null Hypothesis $\left(\mathrm{H}_{0}\right)$ is Rejected at 5\% level.. Hence, Average kind of Business run by the Women Entrepreneurs is not Beauty products and cosmetics

\section{Interpretation}

From the above table 2, shows that Women in the age group of 20 years -30 Years are more likely to start their own Online Business as compared to Women in the Age of Below 20 Years and 30 Years- 40 Years and less favourable in the age of above 40 years.

More than half $(61 \%)$ of the Women Entrepreneurs are Married. They are more likely to start their own Online Business after their marriage as compared to Spinster Women Entrepreneurs.

Majority of the Women Entrepreneurs in Online Business are educated in Under Graduate (71\%) followed by Post Graduate (15\%) than in High School (6\%) and Professional Degree (8\%). This shows Women Entrepreneurs has good knowledge in running their E-Business.

The above table indicates that majority of the Women Entrepreneurs in E-Business have less than one year (49\%) of experience. This shows that Women are most likely to start their online business recent times.

Nearly half of the Women Entrepreneurs (41\%) in E-Business are Sole-Proprietors. This shows that Women Entrepreneurs are more likely to be owned and controlled by herself alone.

Most of the Women Entrepreneurs (40\%) have Micro level business. This shows that Women start their business with the idea of minimum investment and maximum profits.

Majority of the Women Entrepreneurs are involved in selling beauty cosmetics and services (18\%) followed by Online marketing (17\%), Food and Catering services (15\%), Online teaching (14\%), Clothing and accessories (13\%) and less involved in Web designing (4\%), Consultancy services (3\%), Event organization (3\%), Retail selling (3\%), Gift selling (3\%), Tourism booking services (2\%), Health care services (2\%), Bidding services (2\%) and Professional services (1\%). 


\subsection{Impact Faced by women Entrepreneurs in Online Business During COVID- 19}

Impact of COVID-19 pandemic on Women Digital Entrepreneurs are analysed using Multivariate Analysis of Variance (MANOVA) and One sample t-test.

The eruption of COVID-19 made a severe impact on business activity with $38 \%$ of surveyed Women digital entrepreneurs business reporting a temporary shutdown of business activity against $9 \%$ reporting permanent closure of their business and 53\% of surveyed Women Entrepreneurs reported continuity of business. The reasons for temporary shutdown of business during COVID-19 reported out of 38\%, $42 \%$ of respondents says due to reduced orders. out of $38 \%, 26 \%$ of respondents says due to commutation, out of $38 \%, 13 \%$ of respondents says due to lack of Knowledge among customers, out of $38 \%, 18 \%$ of respondents says due to lack of workforce.

Market losses, liquidity shortage, supply difficulty appear to be the challenges faced by the surveyed Women Digital Entrepreneurs related to COVID-19 outbreak. 46\% of surveyed Women Entrepreneurs reports that they face up to $25 \%$ financial loss in their business, $21 \%$ of Women Entrepreneurs face 25\%-50\% financial losses, $18 \%$ of Women Entrepreneurs face more than $50 \%$ of financial losses in their business. $15 \%$ of the surveyed Women Entrepreneurs have earned profit in their business during COVID-19.

The Women Entrepreneurs not only experience financial loss and financial profit but also experienced the change in customer's demand for their product. $53 \%$ of the respondents faced no change in their product demand, $35 \%$ of the respondent faced decrease in demand for their product and $12 \%$ of the respondent faced increase in demand for their product.

\subsubsection{Interrelationship Between Experience in Online Business with Financial Problems, Change in Demand among customers, and shutdown of business faced by Women Digital Entrepreneurs during COVID-19.}

\section{Variables:}

\section{Dependent Variable:}

- Financial Problems faced by Women Digital Entrepreneurs during COVID-!9.

- Change in Demand among the customers towards their products during COVID-19.

- Shutdown of their business during COVID-19

\section{Independent variable:}

Experience of Women Entrepreneurs in E-Business.

\section{Hypothesis:}

\section{Null-Hypothesis}

$\mathrm{H}_{01}$ : There is no significant relationship between Experience in online business between Financial Problems faced by Women Digital Entrepreneurs during COVID-19.

$\mathrm{H}_{\mathrm{o} 2}$ : There is no significant relationship between Experience in online business between Customer's change their demand for products faced by Women Digital Entrepreneurs during COVID-19.

$\mathrm{H}_{03}$ : There is no significant relationship between Experience in online business between Temporary Shutdown of business faced by Women Digital Entrepreneurs during COVID-19. 


\section{Alternative Hypothesis}

$\mathrm{H}_{\mathrm{a} 1}$ : There is a significant relationship between Experience in online business between Financial Problems faced by Women Digital Entrepreneurs during COVID-19.

$\mathrm{H}_{\mathrm{a} 2}$ : There is a significant relationship between Experience in online business between Customer's change their demand for products faced by Women Digital Entrepreneurs during COVID-19.

$\mathrm{H}_{\mathrm{a} 3}$ : There is a significant relationship between Experience in online business between Temporary Shutdown of business faced by Women Digital Entrepreneurs during COVID-19.

Table 3

\begin{tabular}{|c|c|c|c|}
\hline \multicolumn{4}{|c|}{ Between-Subjects Factors } \\
\hline & & Value Label & $\mathbf{N}$ \\
\hline \multirow{4}{*}{$\begin{array}{l}\text { Experience in E-Business of the } \\
\text { Respondents }\end{array}$} & 1.00 & $0-1$ year & 15 \\
\hline & 2.00 & 1 year- 3 years & 18 \\
\hline & 3.00 & 3 years- 5 years & 4 \\
\hline & 4.00 & Above 5 years & 1 \\
\hline
\end{tabular}

(Source: Primary)

Table 4

\begin{tabular}{|ll|c|c|c|c|c|}
\hline \multicolumn{8}{|c|}{ Multivariate Tests $^{\mathrm{a}}$} \\
\hline \multirow{3}{*}{ Intercept } & Effect & Value & $\mathbf{F}$ & Hypothesis df & Error df & Sig. \\
& Pillai's Trace & .895 & $90.789^{\mathrm{b}}$ & 3.000 & 32.000 & .000 \\
\cline { 2 - 7 } & Wilks' Lambda & .105 & $90.789^{\mathrm{b}}$ & 3.000 & 32.000 & .000 \\
\cline { 2 - 7 } & Hotelling's Trace & 8.512 & $90.789^{\mathrm{b}}$ & 3.000 & 32.000 & .000 \\
\cline { 2 - 7 } & Roy's Largest Root & 8.512 & $90.789^{\mathrm{b}}$ & 3.000 & 32.000 & .000 \\
\hline Exp & Pillai's Trace & 1.002 & 5.684 & 9.000 & 102.000 & .000 \\
\cline { 2 - 7 } & Wilks' Lambda & .186 & 8.620 & 9.000 & 78.030 & .000 \\
\cline { 2 - 7 } & Hotelling's Trace & 3.378 & 11.509 & 9.000 & 92.000 & .000 \\
\cline { 2 - 7 } & Roy's Largest Root & 3.066 & $34.744^{\mathrm{c}}$ & 3.000 & 34.000 & .000 \\
\hline
\end{tabular}

(Source: Primary)

Table 5

\begin{tabular}{|c|c|c|c|c|c|c|}
\hline \multicolumn{7}{|c|}{ Tests of Between-Subjects Effects } \\
\hline Source & Dependent Variable & $\begin{array}{l}\text { Type III Sum } \\
\text { of Squares }\end{array}$ & Df & Mean Square & $\mathbf{F}$ & Sig. \\
\hline \multirow[t]{3}{*}{ Corrected Model } & $\begin{array}{l}\text { Financial Problems faced } \\
\text { by Women Entrepreneurs } \\
\text { in E-Business During } \\
\text { COVID_19 }\end{array}$ & $6.502^{\mathrm{a}}$ & 3 & 2.167 & 4.532 & .009 \\
\hline & $\begin{array}{l}\text { Reason for Temporary shut } \\
\text { down of business }\end{array}$ & $33.985^{b}$ & 3 & 11.328 & 26.064 & .000 \\
\hline & $\begin{array}{l}\text { Change in product demand } \\
\text { of customers faced by } \\
\text { Women Entrepreneur } \\
\text { during COVID_19 }\end{array}$ & $4.140^{c}$ & 3 & 1.380 & 1.522 & .226 \\
\hline Intercept & $\begin{array}{l}\text { Financial Problems faced } \\
\text { by Women Entrepreneurs } \\
\text { in E-Business During } \\
\text { COVID_19 }\end{array}$ & 42.896 & 1 & 42.896 & 89.691 & .000 \\
\hline
\end{tabular}


The State of Women Digital Entrepreneurs in India During Covid-19 Pandemic

\begin{tabular}{|c|c|c|c|c|c|c|}
\hline & $\begin{array}{l}\text { Reason for Temporary shut } \\
\text { down of business }\end{array}$ & 82.054 & 1 & 82.054 & 188.785 & .000 \\
\hline & $\begin{array}{l}\text { Change in product demand } \\
\text { of customers faced by } \\
\text { Women Entrepreneur } \\
\text { during COVID_19 }\end{array}$ & 54.737 & 1 & 54.737 & 60.358 & .000 \\
\hline \multirow[t]{3}{*}{ Exp } & $\begin{array}{l}\text { Financial Problems faced } \\
\text { by Women Entrepreneurs } \\
\text { in E-Business During } \\
\text { COVID_19 }\end{array}$ & 6.502 & 3 & 2.167 & 4.532 & .009 \\
\hline & $\begin{array}{l}\text { Reason for Temporary shut } \\
\text { down of business }\end{array}$ & 33.985 & 3 & 11.328 & 26.064 & .000 \\
\hline & $\begin{array}{l}\text { Change in product demand } \\
\text { of customers faced by } \\
\text { Women Entrepreneur } \\
\text { during COVID_19 }\end{array}$ & 4.140 & 3 & 1.380 & 1.522 & .226 \\
\hline \multirow[t]{3}{*}{ Error } & $\begin{array}{l}\text { Financial Problems faced } \\
\text { by Women Entrepreneurs } \\
\text { in E-Business During } \\
\text { COVID_19 }\end{array}$ & 16.261 & 34 & .478 & & \\
\hline & $\begin{array}{l}\text { Reason for Temporary shut } \\
\text { down of business }\end{array}$ & 14.778 & 34 & .435 & & \\
\hline & $\begin{array}{l}\text { Change in product demand } \\
\text { of customers faced by } \\
\text { Women Entrepreneur } \\
\text { during COVID_19 }\end{array}$ & 30.833 & 34 & .907 & & \\
\hline \multirow[t]{3}{*}{ Total } & $\begin{array}{l}\text { Financial Problems faced } \\
\text { by Women Entrepreneurs } \\
\text { in E-Business During } \\
\text { COVID_19 }\end{array}$ & 187.000 & 38 & & & \\
\hline & $\begin{array}{l}\text { Reason for Temporary shut } \\
\text { down of business }\end{array}$ & 213.000 & 38 & & & \\
\hline & $\begin{array}{l}\text { Change in product demand } \\
\text { of customers faced by } \\
\text { Women Entrepreneur } \\
\text { during COVID_19 }\end{array}$ & 191.000 & 38 & & & \\
\hline \multirow[t]{3}{*}{ Corrected Total } & \begin{tabular}{|l|} 
Financial Problems faced \\
by Women Entrepreneurs \\
in E-Business During \\
COVID_19
\end{tabular} & 22.763 & 37 & & & \\
\hline & $\begin{array}{l}\text { Reason for Temporary shut } \\
\text { down of business }\end{array}$ & 48.763 & 37 & & & \\
\hline & $\begin{array}{l}\text { Change in product demand } \\
\text { of customers faced by } \\
\text { Women Entrepreneur } \\
\text { during COVID_19 }\end{array}$ & 34.974 & 37 & & & \\
\hline \multicolumn{7}{|c|}{ a. $\mathrm{R}$ Squared $=.286($ Adjusted R Squared $=.223)$} \\
\hline \multicolumn{7}{|c|}{ b. R Squared $=.697$ (Adjusted R Squared $=.670)$} \\
\hline
\end{tabular}

(Source: Primary)

\section{Interpretation}

Since the $\mathrm{p}$ value for Financial problems faced by Women Digital Entrepreneurs during COVID-19 with their Experience in their Online Business $(0.009)$ is less than $(<) 0.05 . \mathrm{H}_{01}$ is Rejected at 5\% level. Hence, There is a significant relationship between Experience in online business between Financial Problems faced by Women Digital Entrepreneurs during COVID19. 
The $\mathrm{p}$ value for Customer's change their demand for products faced by Women Digital Entrepreneurs during COVID-19 with their Experience in their Online Business (0.226) is More than (>) $0.05 . \mathrm{H}_{02}$ is Accepted at $5 \%$ level. Hence, There is no significant relationship between Experience in online business between Customer's change their demand for products faced by Women Digital Entrepreneurs during COVID-19.

The $\mathrm{p}$ value for Temporary Shutdown of business faced by Women Digital Entrepreneurs during COVID-19 with their Experience in their Online Business $(0.000)$ is less than $(<) 0.05$. $\mathrm{H}_{03}$ is Rejected at $5 \%$ level. Hence, There is a significant relationship between Experience in online business between Temporary Shutdown of business faced by Women Digital Entrepreneurs during COVID-19.

\subsubsection{Impact faced by Women Entrepreneurs in online business during COVID-19}

\section{Hypothesis:}

$\mathrm{H}_{0}$ : There is no significant difference between the various kinds of impact faced by Women Digital Entrepreneurs During COVID-19.

$\mathrm{H}_{1}$ : There is a significant difference between the various kinds of impact faced by Women Digital Entrepreneurs During COVID-19.

Table 6 Kinds of impact faced by Women Digital Entrepreneurs during COVID-19

\begin{tabular}{|l|c|c|c|c|c|c|c|}
\hline \multicolumn{1}{|c|}{$\begin{array}{l}\text { Kind of } \\
\text { Impact }\end{array}$} & $\mathbf{N}$ & Mean & $\begin{array}{l}\text { Standard } \\
\text { Deviation }\end{array}$ & Mean Difference & T Value & $\begin{array}{c}\text { Degree of } \\
\text { freedom }\end{array}$ & Sig. \\
\hline $\begin{array}{l}\text { Improved the } \\
\text { situation of } \\
\text { your Business }\end{array}$ & 100 & 2.5900 & 1.33405 & -.41000 & -3.073 & 99 & $.003^{*}$ \\
\hline $\begin{array}{l}\text { Affected your } \\
\text { Business } \\
\text { situation }\end{array}$ & 100 & 2.6800 & 1.36241 & -.32000 & -2.349 & 99 & $.021^{*}$ \\
\hline $\begin{array}{l}\text { Operation of } \\
\text { Business is } \\
\text { impossible }\end{array}$ & 100 & 2.6800 & 1.46942 & -.32000 & -2.178 & 99 & $.032^{*}$ \\
\hline $\begin{array}{l}\text { Increased the } \\
\text { number of } \\
\text { online shoppers }\end{array}$ & 100 & 2.4300 & 1.14816 & -.57000 & -4.964 & 99 & $.000^{*}$ \\
\hline $\begin{array}{l}\text { Increased the } \\
\text { sales of your } \\
\text { Business }\end{array}$ & 100 & 2.9600 & 1.28645 & -.04000 & -.311 & 99 & $.757^{* * *}$ \\
\hline $\begin{array}{l}\text { Decreased the } \\
\text { sales of Your } \\
\text { Business }\end{array}$ & 100 & 2.6700 & 1.26375 & -.33000 & -2.611 & 99 & $.010^{*}$ \\
\hline
\end{tabular}

(Source: primary)

*significant at $1 \% \quad * *$ significant at $5 \%$

\section{Interpretation}

The P Value of Variables improved the situation of Women Entrepreneur's Business during COVID-19 (2.59) and Increased the number of online shoppers during COVID-19 (2.43) are less than the 0.01 at $1 \%$ level of Significance. Hence, Null Hypothesis is rejected $\left(\mathrm{H}_{0}\right)$. It conclude that there is significance difference in the positive impact of COVID-19 on Women Entrepreneurs business Situation and their online shoppers.

The $\mathrm{P}$ Value of variables of negative impact on Women Entrepreneurs business Situation (2.68), Operation of Business becomes impossible (2.68) and decrease in their sales (2.67) are more than (>) 0.01 at $1 \%$ level of Significance. Hence, Null Hypothesis $\left(\mathrm{H}_{0}\right)$ is Accepted at $1 \%$. 
It concludes that there is no significance difference in the negative impact of COVID-19 on Women Entrepreneur's Business situation, their business operations and sales.

The P Value of variable increase of sales of Women Digital Entrepreneurs Business during COVID-19 (2.96) is more than (>) $0.05 \%$ at $5 \%$ level of Significance. Hence, Null Hypothesis $\left(\mathrm{H}_{0}\right)$ is Accepted. It concludes that there is no Significance difference in positive impact of COVID-19 on Women Digital Entrepreneurs in Increasing their sales.

\subsection{Strategies adopted by Women Digital Entrepreneurs in attracting Customers during COVID-19}

Today, it is difficult to anticipate the full recover of COVID-19 pandemic situation. This situation has effected many peoples especially Small Women entrepreneurs, as they face difficult to sustain without doing anything to generate revenue. This creates the need for adoption of some strategies in order to attract and sustain their existing and new customers.

Table 7 Strategies adopted by Women Digital Entrepreneurs

\begin{tabular}{|l|c|c|c|}
\hline \multicolumn{1}{|c|}{ Strategies } & No. of Respondents & Percentage (\%) & $\begin{array}{c}\text { Cumulative } \\
\text { Percentage (\%) }\end{array}$ \\
\hline $\begin{array}{l}\text { Frequent updates in websites and social } \\
\text { channels }\end{array}$ & 23 & 23.0 & 23.0 \\
\hline Free samples and gifts & 27 & 27.0 & 50.0 \\
\hline $\begin{array}{l}\text { Fast delivery of products and Good } \\
\text { Customer services }\end{array}$ & 7 & 7.0 & 57.0 \\
\hline Providing offers and discounts & 9 & 9.0 & 66.0 \\
\hline Maintaining Blogs & 4 & 4.0 & 70.0 \\
\hline e-mail marketing & 12 & 12.0 & 82.0 \\
\hline Making Websites attractive & 18 & 18.0 & 100.0 \\
\hline Total & 100 & 100.0 & \\
\hline
\end{tabular}

(Source: Primary)

From the above table 7, shows that the main strategy preferred by the respondents is frequent updation in websites and social channels (27\%). Besides, providing free samples to the customers (23\%), making websites attractive (18\%), marketing through E-mail (12\%), providing offers and discounts (9\%), Good customer services (7\%) and maintaining blogs (4\%). These strategies could help Women Digital Entrepreneur's business to grow as well as increase their revenues.

\subsubsection{Inter-relationship between Kinds of online business and Strategies used by Women Digital Entrepreneurs in attracting the customers during COVID-19}

\section{Hypothesis:}

$\mathrm{H}_{0}$ : There is no significance association between kinds of business and strategies used by Women Digital Entrepreneurs in attracting customers during COVID-19

$\mathrm{H}_{1}$ : There is a significance association between kinds of business and strategies used by Women Digital Entrepreneurs in attracting customers during COVID-19.

Dependent Variable: Strategies used in attracting customers.

Independent variable : Kinds of Online Business run by Women Entrepreneurs. 
Table 8 Relationship Between Kinds of E-Business and Strategies used by Women Digital Entrepreneurs during COVID-19

\begin{tabular}{|c|c|c|c|c|c|c|c|c|c|c|c|c|c|c|c|}
\hline Strategies & & & & & & & nds of E-B & Business & & & & & & & \\
\hline $\begin{array}{c}\text { Women } \\
\text { Digital } \\
\text { Entreprene } \\
\text { urs in } \\
\text { attracting } \\
\text { the } \\
\text { Customers } \\
\text { during } \\
\text { COVID-19 }\end{array}$ & $\begin{array}{c}\text { Online } \\
\text { Marketi } \\
\text { ng }\end{array}$ & $\begin{array}{c}\text { Clothing } \\
\text { and } \\
\text { Accessori } \\
\text { es }\end{array}$ & $\begin{array}{c}\text { Online } \\
\text { teachi } \\
\text { ng }\end{array}$ & $\begin{array}{c}\text { Food } \\
\text { and } \\
\text { Cateri } \\
\text { ng } \\
\text { service } \\
\text { s }\end{array}$ & \begin{tabular}{|l} 
Beauty \\
cosmeti \\
cs and \\
services
\end{tabular} & \begin{tabular}{|} 
online \\
Consultan \\
cy \\
services
\end{tabular} & $\begin{array}{c}\text { Travelli } \\
\text { ng and } \\
\text { Tourism } \\
\text { Services }\end{array}$ & $\begin{array}{c}\text { online } \\
\text { Professio } \\
\text { nal } \\
\text { Services }\end{array}$ & $\begin{array}{c}\text { Online } \\
\text { Health } \\
\text { Care } \\
\text { Servic } \\
\text { es }\end{array}$ & $\underset{\substack{\text { Event } \\
\text { Organizi } \\
\text { ng }}}{ }$ & $\begin{array}{c}\text { Web } \\
\text { Designi } \\
\text { ng }\end{array}$ & $\begin{array}{c}\text { Retai } \\
1 \\
\text { i } \\
\text { sellin } \\
\mathbf{g}\end{array}$ & $\mid \begin{array}{c}\text { onlin } \\
\text { e } \\
\text { Gifts } \\
\text { selle } \\
\text { rs }\end{array}$ & \begin{tabular}{|} 
online \\
biddin \\
g \\
ervic \\
es
\end{tabular} & Tot \\
\hline $\begin{array}{l}\text { Frequent } \\
\text { updates in } \\
\text { websites } \\
\text { and social } \\
\text { channels }\end{array}$ & 3 & 0 & 2 & 2 & 4 & 0 & 0 & 1 & 2 & \begin{tabular}{|c|}
3 \\
\end{tabular} & 4 & 0 & 0 & 2 & 23 \\
\hline $\begin{array}{l}\text { Free } \\
\text { samples } \\
\text { and gifts }\end{array}$ & 11 & 5 & 3 & 0 & 6 & 1 & 1 & 0 & 0 & 0 & 0 & 0 & 0 & 0 & 27 \\
\hline \begin{tabular}{|l|} 
Fast \\
delivery of \\
products \\
and Good \\
Customer \\
services \\
\end{tabular} & 0 & 2 & 1 & 1 & 2 & 1 & 0 & 0 & 0 & 0 & 0 & 0 & 0 & 0 & 7 \\
\hline $\begin{array}{l}\text { Providing } \\
\text { offers and } \\
\text { discounts }\end{array}$ & 3 & 1 & 0 & 2 & 0 & 1 & 1 & 0 & 0 & 0 & 0 & 1 & 0 & 0 & 9 \\
\hline $\begin{array}{l}\text { Maintainin } \\
\text { g Blogs }\end{array}$ & 0 & 0 & 0 & 2 & 0 & 0 & 0 & 0 & 0 & 0 & 0 & 1 & 1 & 0 & 4 \\
\hline $\begin{array}{l}\text { e-mail } \\
\text { marketing }\end{array}$ & 0 & 4 & 0 & 3 & 3 & 0 & 0 & 0 & 0 & 0 & 0 & 1 & 1 & 0 & 12 \\
\hline $\begin{array}{l}\text { Making } \\
\text { Websites } \\
\text { attractive }\end{array}$ & 0 & 1 & 8 & 5 & 3 & 0 & 0 & 0 & 0 & 0 & 0 & 0 & 1 & 0 & 18 \\
\hline Total & 17 & 13 & 14 & 15 & 18 & 3 & 2 & 1 & 2 & 3 & 4 & 3 & 3 & 2 & 100 \\
\hline
\end{tabular}

(Source: Primary)

\section{Analysis of Variance Table}

Table 9

\begin{tabular}{|l|c|c|c|c|c|}
\hline \multicolumn{1}{|c|}{ Source of Variation } & Sum of Squares & $\begin{array}{c}\text { Degree of } \\
\text { Freedom }\end{array}$ & Mean Square & F & Sig. \\
\hline Between Groups & 193.998 & 13 & 14.923 & 4.024 & .000 \\
\hline Within Groups & 318.962 & 86 & 3.709 & & \\
\hline Total & 512.960 & 99 & & & \\
\hline
\end{tabular}

ndf $=99$, The test Statistic $\mathrm{F}_{\mathrm{c}}=4.024$

Table value of $\mathrm{F}$ at $5 \%$ level $=1.83569$

Since, the calculated value of $\mathrm{F}$ is 4.024 which is greater than (>) the Table value of $\mathrm{F}$ (1.83569) $\mathrm{H}_{0}$ is rejected. Hence there is significant association between kinds of business and strategies used by Women Digital Entrepreneurs in attracting customers during COVID-19.

\section{Interpretation}

The P value of variable $(0.000)$ is less than $(<) 0.05$. Hence, Null Hypothesis is Rejected. The result is that there is significance association between kinds of business and strategies used by Women Digital Entrepreneurs in attracting customers during COVID-19. 


\section{FINDINGS}

This study reports that most respondents of Women Digital Entrepreneurs belongs to the age group of 20- 30 years and have qualification of Under Graduate. Most of the Women Entrepreneurs are married and have less than one year of experience. Maximum number of respondents of Women Digital Entrepreneurs are Sole-Proprietors and have Micro level business.

From the above analysed data, it shows that by accepting the Null Hypothesis (H0) Average age of the respondents belong to the age group of 20 years- 30 Years, Average years of Experience of the respondents have in E-Business is 1year - 3 Years, Average number of respondents are Retailers and Average size of the online business run by Women Entrepreneur is small scale Business. By rejecting the Null Hypothesis, Average Marital Status of the Respondents are not Spinster, Average Education Qualification of the Respondents does not have Under Graduate Degree and Average kind of Business run by the Women Entrepreneurs is not Beauty products and cosmetics.

Positive impact of COVID-19 on Women Digital Entrepreneurs reveals that, by rejecting Null Hypothesis $\left(\mathrm{H}_{0}\right)$ at $1 \%$ level, concludes that there is significance difference in the positive impact of COVID-19 on Women Entrepreneurs business Situation and their online shoppers. By accepting Null Hypothesis $\left(\mathrm{H}_{0}\right)$ at $5 \%$ level, concludes that there is no Significance difference in positive impact of COVID-19 on Women Digital Entrepreneurs in Increasing their sales.

Negative impact of COVID-19 on Women Digital Entrepreneurs reveals that, by accepting Null Hypothesis $\left(\mathrm{H}_{0}\right)$ at $1 \%$ level, concludes that there is no significance difference in the negative impact of COVID-19 on Women Entrepreneur's Business situation, their business operations and sales.

The relationship between Experience in Online Business with Financial Problems, Change in Demand among customers, and shutdown of business faced by Women Digital Entrepreneurs during COVID-19, MANOVA clearly indicates that

a) There is a significant relationship between Experience in online business between Financial Problems faced by Women Digital Entrepreneurs during COVID-19.

b) There is no significant relationship between Experience in online business between Customer's change their demand for products faced by Women Digital Entrepreneurs during COVID-19.

c) There is a significant relationship between Experience in online business between Temporary Shutdown of business faced by Women Digital Entrepreneurs during COVID-19.

The main strategy preferred by the respondents in attracting customers during COVID-19 is frequent updates of websites and social channels (27\%). Besides, providing free samples to the customers (23\%), making websites attractive (18\%), marketing through E-mail (12\%), providing offers and discounts (9\%), Good customer services (7\%) and maintaining blogs (4\%). These strategies could help Women Digital Entrepreneur's business to grow as well as increase their revenues.

The interrelationship between kinds of E-Business and strategies used by Women Digital Entrepreneurs in attracting customers during COVID-19, one way ANOVA clearly states that there is significance association between kinds of business and strategies used by Women Digital Entrepreneurs in attracting customers during COVID-19. 


\section{SUGGESTIONS}

Women Entrepreneurs can be encouraged to start their business as joint stock companies and co-operative business rather than being a sole-traders or partnership concerns to avail advantage of large scale operations.

For increasing the participation of Women Entrepreneurs in online business, Government has to provide more fund as well as train more trainers so that the opportunity, survivability, profitability and sustainability of their business activities can be achieved.

It is recommended that the government has to provide more funds, develop adequate infrastructure as well as make arrangement of training to encourage Women entrepreneurs to participate in online business so that the opportunity, survivability, profitability and sustainability of their business activities can occur. And make sure that funds remains available for innovative start-ups at all stages of development.

Awareness can be created about existing measures and support initiatives which provide guidance to help Women Digital Entrepreneurs to adapt to COVID-19 crisis by educating them through official platforms that centralize information on various support programs, provide advice on cash flow management etc.

Reduction of barriers associated with Women Entrepreneurs, those who suffer during and after COVID-19 pandemic by accessing them health care facilities, paid sick leave etc.

\section{CONCLUSIONS}

COVID-19 pandemic has made drastic change in way of living to virtual to some extent in order to practice social distancing, washing hands and get accustomed to wearing mask COVID-19 pandemic has shown massive growth in Digital business ventures especially for Women. Today, in this COVID-19 pandemic situation, participation of Women Entrepreneurs in online business has been increasing at considerable rate. New born women entrepreneurs are emerged with new opportunities by transforming their existing knowledge, skills, employees and networks to new needs that have emerged.

This study shows that Women Digital Entrepreneurs have temporary shutdown of their business and financial problems faced by them during COVID-19 pandemic has significant relationship with experience in their E-Business. And change in product demand of customers during COVID-19 has no significant association with experience in Online Business. This study reveals that COVID-19 has both positive and negative impact on Women Digital Entrepreneurs. Positive impact of improving their business situation and increasing number of online shoppers has significant relationship with kinds of online business runs by women entrepreneurs and increase in sale has no influence on Women Entrepreneurs during COVID-19. Negative impact of Women Digital Entrepreneurs of adverse affect of their business, decrease in sales and impossible operation of their business during COVID-19 has no significant difference in kinds of online business run by them. This study discuss about various strategies used by Women Entrepreneurs in attracting customers during COVID-19 has significant association between kinds of online business run by them. This shows that strategies like providing free samples, active participation in social media, creating attractive business blogs etc. plays a significant role not only attracting new customers but also helps in retaining existing customers during COVID-19 pandemic. On the basis of findings, it states that Women Entrepreneurial activity will be increased both during and after COVID-19 pandemic which will ultimately help Women Entrepreneurs to grow digitally in future. 


\section{REFERENCES}

[1] Susmitha Kunchaparthi (2021)- "Impact of COVID 19 on E-Commerce"- Journal of Interdisciplinary Cycle Research- Volume XII, Issue IX, September/2020 ISSN NO: 00221945- PP. 1161- 1165.

[2] Risqo M. Wahid, Diah Isnaini Asiati (2021)- "Women MSMEs and Covid-19: Social Media Marketing as a Survival Strategy"- International Journal of Innovative Science and Research Technology - ISSN No:-2456-2165- Volume 6, Issue 2- PP.368- 378- www.ijisrt.com.

[3] Salome K. Kaberia, Stephen M.A. Muathe (2021) - "Effect of Covid-19 Pandemic on Performance of Women Owned Micro, Small and Medium Enterprises in Kenya"- International Journal of Social Science Studies- Volume. 9, No. 1- ISSN 2324-8033 E-ISSN 2324-8041 http://ijsss.redfame.com

[4] Anam Bhatti, Hamza Akram, Hafiz Muhammad Basit, Ahmed Usman Khan, Syeda Mahwish Raza, Naqvi, Muhammad Bilal (2020)- "E-commerce trends during COVID-19 Pandemic"International Journal of Future Generation Communication and Networking- ISSN: 22337857- Vol. 13, No. 2- pp.1449-1452.

[5] Luca Koltai, Virag Zsar, Andrea Petroczi (2020)- "COVID-19 and female entrepreneurs throughout Europe"- HETFA Research Institute Ltdhttps://www.researchgate.net/publication/344665139

[6] Madhavilatha Sangem (2020)- "Challenges for Women Entrepreneurs in the Wake of COVID 19 Pandemic"- Journal of Interdisciplinary Cycle Research- ISSN NO: 0022-1945- Volume XII, Issue XI- PP. 279-284

[7] Tatiana S Manolova, Candida G Brush, Linda F Edelman, (2020) "Pivoting to stay the course: How women entrepreneurs take advantage of opportunities created by the COVID 19 pandemic"- International Small Journal : Researching Entrepreneurship - Volume 38, issue 6- PP. 481-491- https://journals.sagepub.com/doi/full/10.1177/0266242620949136

[8] Saipriya Salla, (2020)- "How will COVID 19 Affect Women Entrepreneurs?"- Internet- Source: http://www.ipsnews.net/2020/07/will-COVID 19-affect-women-entrepreneurs/

[9] Siti Masayu Rosliah Abdul Rashid, Fathimah Hassan and Kurshiah Ahamad (2020)- "Post Covid-19 Online Business Strategies by Small-Scale Entrepreneurs in Malaysia- International Journal of Academic Research in Business and Social Science- ISSN: 2222-6990http://dx.doi.org/10.6007/IJARBSS/v10-i9/7635

[10] Madhobi Hossain, Mayeesha Fairuz Rahman (2018)- "Social Media and the Creation of Entrepreneurial Opportunity for Women”- DOI: 10.5923/j.mm.20180804.02

[11] Akhila Pai H (2018)-“Digital Startups and Women Entrepreneurship : A Study on status of Women Entrepreneurs in India" - e ISSN 2348 -1269, Print ISSN 2349-5138- Volume 5, Issue 4- http://ijrar.com/

[12] Eunice Mukolwe, Dr. Jacqueline Korir (2016)- "Social Media and Entrepreneurship: Tools, Benefits, and Challenges. A Case Study of Women Online Entrepreneurs on Kilimani Mums Marketplace on Facebook", International Journal of Humanities and Social Science, Vol. 6, No. 8, ISSN 2220-8488 (Print), 2221-0989 (Online), PP. 248-256, www.ijhssnet.com.

[13] Impact of Covid-19 on Women Entrepreneurs- Women Entrepreneurship knowledge Hub

[14] Leila Mivehchi (2019)- "The Role of Information Technology in Women Entrepreneurship (The Case of E-Retailing in Iran) "- 3rd World Conference on Technology, Innovation and Entrepreneurship (WOCTINE)- www.sciencedirect.com

[15] Dr. Bimal Anjum, Rajesh Tiwari (2012) - "Role of Information Technology in Women Empoerment"- International Journal of Multidisciplinary Management Studies- Vol.2 Issue 1ISSN 2249-8834, PP 226-223

https://iaeme.com/Home/journal/IJARET 533 editor@iaeme.com 